\title{
Soil seed banks of pioneer tree species in European temperate forests:
}

\section{a review}

\author{
Katharina Tiebel, \\ Franka Huth, \\ Sven Wagner
}

\section{Introduction}

Soil seed banks are an important component in the succession and regeneration of ecosystems. Soil seed banks are buried seed reserves, which are viable and able to germinate under changing environmental conditions (Fenner 1985, Thompson et al. 1997, Berger et al. 2004). The formation of a soil seed bank is a strategy developed by plants to prevent germination under unfabeer 1988, Leck et al. 2008, Saatkamp et al. 2014). In disturbed areas of forest, seeds of different species are granted an opportuvorable soil and climate conditions (Brad-

The ability of short-lived tree species such as birch, alder, willow, poplar and rowan to form even a short-term soil seed bank is discussed controversially in the literature. Soil seed banks are an important component of succession and regeneration in ecosystems. Following disturbance, buried viable seeds germinate and the seedlings that establish cover the disturbed, exposed soil surfaces. The objective of this study was to review the literature on soil seed bank research carried out in central and north-west European temperate forests to provide an overview of the ability of pioneer tree species to form a viable seed bank. The review of 33 publications revealed that birch is the only pioneer tree species of temperate forests with longer-lived seeds, persisting in the soil for 1-5 years. Birch seeds remain viable in deeper soil layers (5-10 $\mathrm{cm})$, so birch may be assigned to the short-term persistent soil seed bank type. The seeds of alder, willow and poplar would appear to be short-lived. Maximum seed densities of all tree species were found in the upper soil layers. With increasing soil depth, seed density declined. Viable seeds of rowan were not detected in any of the soil seed bank studies, although seed trees were present. We found that in spite of the capacity for long seed dispersal distances, high densities of birch, alder and willow seeds were only observed in close proximity to seed trees. The higher the numbers of seed trees, the higher the seed densities in soils. Maximum seed densities were recorded during and shortly after seed rains had occurred. Our results reveal that a birch seed bank may compensate for years of low seed production levels. However, as the seed bank is only short-term persistent, it must be supplemented by fresh seeds from surrounding seed trees as often as possible to guarantee a continuous capacity for regeneration.

Keywords: Betula, Buried Seeds, Propagule Bank, Seed Density, Viable Seeds, Germination nity to germinate and cover the open soil surface, even though these species may not have been represented in this area for long time (Fenner 1985, Bossuyt \& Hermy 2001). Soil seed banks could contribute significantly to the reforestation of disturbed woodlands. They may also compensate for a recent absence of seed sources within or around a damaged area.

Soil seed banks of forests generally exhibit lower species diversity and seed densities than those present in other ecosystems (Kalamees \& Zobel 1998, Hopfensperger 2007, Bossuyt \& Honnay 2008). Decidu- $\square$ Institute of Silviculture and Forest Protection, TU Dresden, Pienner Str. 8, 01737 Tharandt (Germany)

@ Katharina Tiebel (katharina.tiebel@forst.tu-dresden.de)

Received: Feb 09, 2017 - Accepted: Jan 12, 2018

Citation: Tiebel K, Huth F, Wagner S (2018). Soil seed banks of pioneer tree species in European temperate forests: a review. iForest 11: 48-57. - doi: 10.3832/ifor2400-011 [online 2018-01-25]

Communicated by: Michele Carbognani ous, young or managed forests are characterized by larger seed numbers and greater species richness than coniferous, older or unmanaged forests (Donelan \& Thompson 1980, Bossuyt \& Hermy 2001, Godefroid et al. 2006, Ebrecht \& Schmidt 2008, Plue et al. 2010). The seed bank compositions of northern and western European forests differ from those of eastern European forests (Bossuyt et al. 2002). The composition of seed banks and ground flora in forests also differ from each other (Bossuyt \& Hermy 2001, Bossuyt et al. 2002, Zobel et al. 2007). In central European temperate forests, soil seed banks predominantly contain herbaceous plant species of early or middle successional stages. The seed banks are refreshed by seeds of species that emerge in case of disturbance in forest ecosystems. Species of early or middle successional stages are light demanding species, adapted to disturbances, and able to form a persistent soil seed bank (Donelan \& Thompson 1980, Bossuyt et al. 2002, Godefroid et al. 2006). Hopfensperger (2007) suggested that pioneer species, present in early successional stages, can form a persistent seed bank at the beginning of succession to woodland. Seeds of ancient, 
shade-tolerant forest species, shrubs and tree species in general, are not well represented in the soil seed bank, because the seeds of these species do not remain viable for long (Donelan \& Thompson 1980, Bossuyt \& Hermy 2001). However, pioneer tree species are also regarded as light demanding species. In Europe, Betula spp., Salix spp., Populus spp., Alnus spp. and Sorbus aucuparia L. represent deciduous pioneer tree species. These tree species are shortlived species, which produce large quantities of seeds, have long seed dispersal distances and exhibit fast juvenile growth (Perala \& Alm 1990, Raspé et al. 2000, Zerbe 2001). Pioneer tree species are very common in early successional stages and in disturbed woodlands in central Europe (Zerbe 2001). With climate change, and the associated increase in the frequency and intensity of disturbances (e.g., storm events - Seidl et al. 2014), pioneer tree species are of growing importance for natural reforestation, and consequently their soil seed banks too. Pioneer tree species can regenerate rapidly and successfully colonize large areas in years of high seed production (Perala \& Alm 1990, Leder 1992, Raspé et al. 2000, Argus 2006). As a consequence, pioneer tree species can mitigate negative consequences associated with disturbed areas, such as soil erosion and the loss of nutrients (Barnes et al. 1998, Schölch 1998, Argus 2006, Zerbe 2009, Fischer et al. 2016). However, pioneer tree species exhibit irregular seed production patterns (mast years - Sarvas 1952, Bjorkbom 1967, Holm 1994, Osumi \& Sakurai 1997, Sperens 1997, Hynynen et al. 2010). A question that arises is whether pioneer tree species have the potential to regener- ate from a soil seed bank in non-mast years, as shown by Hopfensperger (2007) for pioneer species. Currently little is known about the capacity of pioneer tree species in European temperate forests to establish seed banks, or how long their seeds persist in soil. Some burial experiments showed that rowan and birch seeds remain viable in soil for more than 5 years (Miles 1974, Granström \& Fries 1985, Granström 1987, Skoglund \& Verwijst 1989) and sometimes viable birch and willow seeds were detected in soil samples collected from deeper mineral soil layers (Hill \& Stevens 1981, Staaf et al. 1987, Bakker et al. 1996a, Kalamees \& Zobel 1998, Dölle \& Schmidt 2009). However, the ability of pioneer tree species to form at least a shortterm seed bank is controversial in the literature. The short viability period of pioneer tree seeds after dispersal is often mentioned and many authors support the hypothesis that pioneer tree species do not generally form a seed bank (Hill \& Stevens 1981, Amezaga \& Onaindia 1997, Buckley et al. 1997, Ebrecht \& Schmidt 2008, Heinrichs 2010). By contrast, Granström \& Fries (1985), Osumi \& Sakurai (1997), Erlbeck (1998), Rydgren et al. (1998) and Decocq et al. (2004) suggested that birch, alder and rowan may make up part of the forest seed bank. If pioneer tree species have the capacity to establish a seed bank, years with low levels of fructification can be compensated for and the colonization of open areas, for example, would not depend exclusively on annual seed rain (Osumi \& Sakurai 1997).

In this review, available data pertaining to densities of birch, alder, willow, poplar and rowan in soil seed banks in central and

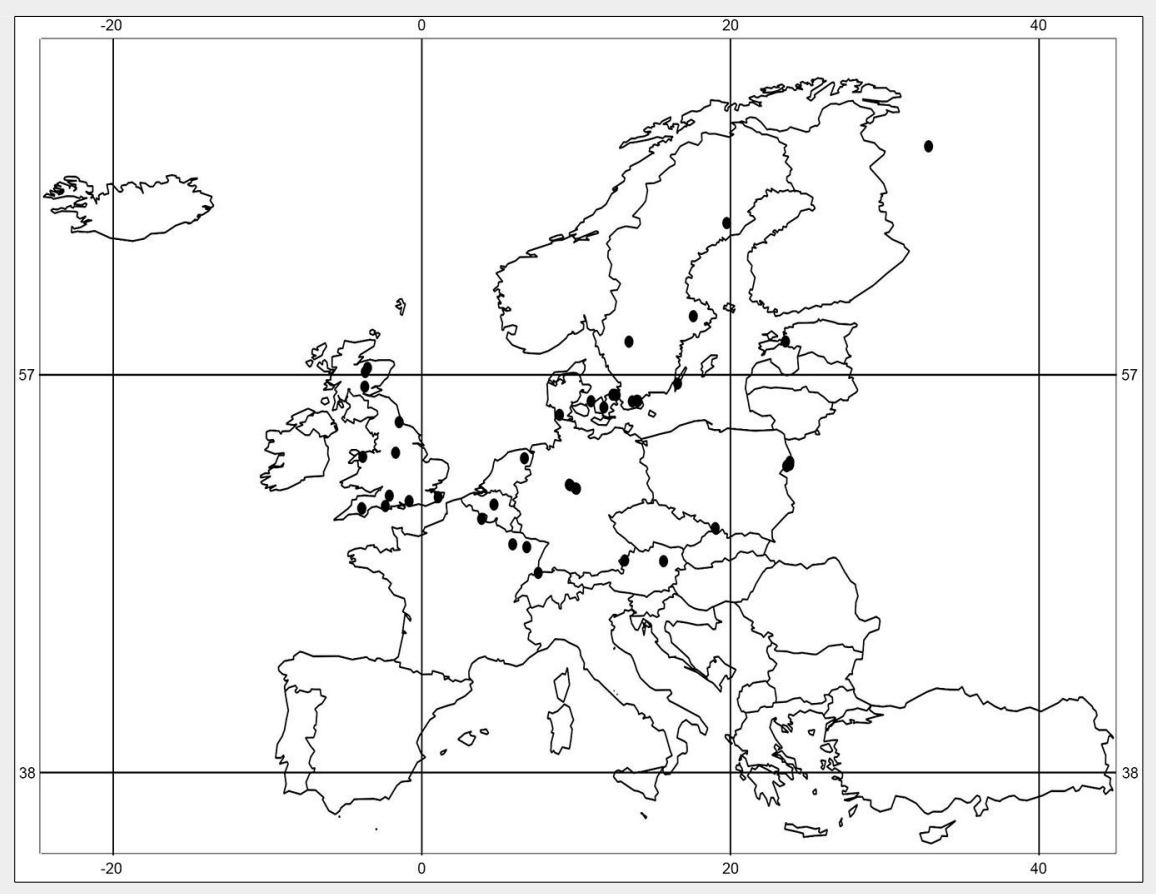

Fig. 1 - Location of the 33 selected soil seed bank studies in Europe.

north-west European temperate forests are documented based on a survey of the literature. The aim was to summarize the general findings and to identify knowledge gaps concerning the soil seed bank with respect to these short-lived tree species. This species-specific information were discussed in the context of the meaning of the soil seed bank, and in relation to disturbance regimes, succession and reproductive ecology.

\section{Methods of literature search}

Our review is based on studies carried out in central and north-west European temperate forests published in the period 19792013. The keywords "seed bank", "propagule bank" and "buried seeds" were used in combination with either "forest" or "woodland". An article was selected when the seed density per $\mathrm{m}^{2}$ could be calculated in order to make the results comparable with those of other studies. A total of 33 studies from 14 countries matched the criteria (Fig. 1). Most of papers were found by searching the "Web of Science" database, meaning the papers had to be published in international peer reviewed journals with an impact factor. Only 3 papers included in the review were published in non-peer reviewed journals, 2 of which were written in English (Ebrecht \& Schmidt 2008, Heinrichs 2010, Jedrzejczak 2013). These papers were found through citations within other international soil seed bank papers. The forests presented in all of the chosen studies were considered to be distinct sample plots wherever the authors classified the study sites and their sample plots as independent (e.g., Staaf et al. 1987, Dougall \& Dodd 1997, Dölle \& Schmidt 2009). In this way, 136 sample plots were recorded, which differed in their histories, forest types, stand ages, canopy densities and management strategies (see Tab. S1 in Supplementary material). The mean seed density per $\mathrm{m}^{2}$ of birch (Betula spp.), alder (Alnus glutinosa [L.] Gaertn.), aspen (Populus tremula L.) and willow (Salix spp.) was calculated for each plot. The soil samples differed in their depths and in terms of the soil layers. Authors took samples from humus and mineral soil, or only from the mineral soil layer. In some cases no information about whether litter and humus were removed prior to sampling was provided (Tab. 1). In this paper the term "birch" is used to represent Betula pendula and B. pubescens, with "Salix spp." used to indicate all willow species detected in soils. This corresponds to the approaches used by the authors of the selected studies.

\section{Species-specific reproductive ecology determining the potential of soil seed banks}

It is often assumed by practitioners that a bountiful fructification of pioneer tree species recurs annually. However, like intermediate and climax tree species, shortlived species exhibit irregular seed produc- 
Tab. 1 - Summary of the 33 selected seed bank studies in central and north-west European temperate forests and the information about seed densities provided. ( $¥)$ Depth of core: (?) not clear whether the humus layer was tested or not; (-) humus layer not tested; (+) humus layer tested separately; (++) humus and mineral soil layer tested together; (5) soil sample depth of $0-5 \mathrm{~cm}$ in the mineral soil. ( $\dagger$ ) Temperature: (1) cold stratification of soil samples before seedling-emergence treatment; (2) cold stratification of soil samples integrated within the seedling-emergence treatment. (§) Species: (?) the species or genus with individually defined small numbers in the soil was excluded from the presentation; $(+)$ species or genus detected; $(-)$ species or genus not detected; $(-/)$ tree species excluded, which germinated in sterile control trays.

\begin{tabular}{|c|c|c|c|c|c|c|c|c|c|c|c|}
\hline \multirow[b]{2}{*}{ Author(s) \& Year } & \multirow[b]{2}{*}{$\begin{array}{l}\text { Date of soil } \\
\text { sampling }\end{array}$} & \multirow[b]{2}{*}{$\begin{array}{l}\text { Depth } \\
\text { of core }{ }^{(\neq)} \\
(\mathrm{cm})\end{array}$} & \multicolumn{2}{|c|}{ Seedling-emergence method } & \multirow[b]{2}{*}{ סृ } & \multirow[b]{2}{*}{ 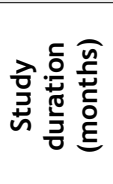 } & \multicolumn{5}{|c|}{ Species $^{(\mathrm{(})}$} \\
\hline & & & $\begin{array}{c}\text { Temperature }{ }^{(t)} \\
\text { (range }{ }^{\circ} \mathrm{C} \\
\text { or day/night) }\end{array}$ & $\begin{array}{l}\text { Artificial } \\
\text { light } \\
\text { (day/night) }\end{array}$ & & & $\frac{0}{3} \dot{0}$ & 突 & $\stackrel{x}{\text { б }}$ & 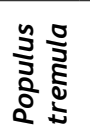 & 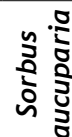 \\
\hline Amrein et al. 2005 & Jan & (-) 10 & $16^{\circ} \mathrm{C}$ & $16 / 8 \mathrm{~h}$ & - & 5 & - & - & - & - & - \\
\hline Augusto et al. 2001 & Feb & $(-) 5$ & $\begin{array}{l}\text { nursery and closed } \\
\text { shade house }\end{array}$ & - & - & 7 & + & - & $-/-$ & - & - \\
\hline Bakker et al. 1996a & Apr & (-) 10 & $25-45 / 15^{\circ} \mathrm{C}$ & - & + & 4.5 & + & - & + & - & - \\
\hline Bekker et al. 2000 & Mar & (?) 10 & $25 / 15^{\circ} \mathrm{C}$ & $12 / 12 \mathrm{~h}$ & + & 3 & + & + & + & - & - \\
\hline Berger et al. 2004 & $\begin{array}{l}\text { Feb, Mar, } \\
\text { Jun, Sept }\end{array}$ & $(+) 35$ & glasshouse & 6-9 pm & - & $3-4$ & + & - & + & - & - \\
\hline Bossuyt et al. 2002 & Mar, Sept & (-) 20 & $14-25^{\circ} \mathrm{C}$ & $16 / 8 \mathrm{~h}$ & - & 5 & + & - & - & - & - \\
\hline Brown \& Oosterhuis 1981 & $\mathrm{Apr}$ & $(-) 15$ & glasshouse $^{(1)}$ & - & - & 24 & + & - & + & - & - \\
\hline Buckley et al. 1997 & Nov-Feb & (?) 10 & $\begin{array}{l}\text { unheated polythene } \\
\text { tunnel }\end{array}$ & - & - & $6-9$ & + & - & - & - & - \\
\hline Decocq et al. 2004 & Jun & $(-) 20$ & $20 / 16^{\circ} \mathrm{C}$ & $12 / 12 \mathrm{~h}$ & - & $6^{(2)}$ & + & + & - & - & - \\
\hline Dölle \& Schmidt 2009 & Mar & $(-) 30$ & unheated glasshouse & - & - & 12 & + & - & + & - & - \\
\hline $\begin{array}{l}\text { Donelan \& Thompson } \\
1980\end{array}$ & May & (?) 7 & unheated glasshouse & - & - & 3 & + & - & - & - & - \\
\hline Dougall \& Dodd 1997 & Apr & $(-) 10$ & $\begin{array}{l}\text { polythene tunnel/ } \\
\text { glasshouse }\end{array}$ & - & - & 4 & + & - & - & - & - \\
\hline Ebrecht \& Schmidt 2008 & Mar & (+) 10 & unheated glasshouse & - & - & 10 & + & - & - & - & - \\
\hline Falinska 1999 & $\begin{array}{l}\text { Mar/Apr, } \\
\text { Sept/Oct }\end{array}$ & (?) 3 & $18-22^{\circ} \mathrm{C}$ & - & + & 36 & + & + & + & - & - \\
\hline Grandin 2001 & Jul & (+) 15 & $22 / 5^{\circ} \mathrm{C}^{(1)}$ & $16 / 8 \mathrm{~h}$ & - & $16^{(2)}$ & + & ? & ? & ? & ? \\
\hline Granström 1982 & Jul & $(+) 5$ & $22 / 12^{\circ} \mathrm{C}^{(1)}$ & $18 / 6 \mathrm{~h}$ & + & 6 & + & - & - & - & - \\
\hline Granström 1988 & Apr & $(+) 6$ & $22 / 12^{\circ} \mathrm{C}^{(1)}$ & $18 / 6 \mathrm{~h}$ & - & $63^{(2)}$ & + & - & + & - & - \\
\hline Heinrichs 2010 & Mar & $(+) 20$ & unheated glasshouse & - & - & 12 & + & $?$ & $-/-$ & + & $?$ \\
\hline Hester et al. 1991 & May & $(++) 5$ & glasshouse & - & - & 12 & + & - & - & - & - \\
\hline Hill \& Stevens 1981 & Apr & $(+) 10$ & unheated glasshouse & - & - & 8 & + & - & - & - & - \\
\hline $\begin{array}{l}\text { Jankowska-Blaszczuk } \\
1998\end{array}$ & Mar & (?) 5 & unheated glasshouse & - & - & 43 & + & - & - & - & - \\
\hline $\begin{array}{l}\text { Jankowska-Blaszczuk et } \\
\text { al. } 1998\end{array}$ & early spring & $(-) 10$ & unheated glasshouse & - & - & 8 & + & - & - & - & - \\
\hline Jaroszewicz 2013 & Jun & $(-) 10$ & unheated glasshouse & - & - & 25 & + & $?$ & $?$ & $?$ & $?$ \\
\hline Jedrzejczak 2013 & Oct, Nov & (?) 10 & $18-24{ }^{\circ} \mathrm{C}$ & $12 / 12 \mathrm{~h}$ & - & 5 & + & - & - & - & - \\
\hline Kalamees \& Zobel 1998 & May & $(-) 10$ & unheated glasshouse & - & - & $>4$ & + & - & - & - & - \\
\hline Kjellsson 1992 & Mar, Apr & $(++) 17.5$ & $22 / 12^{\circ} \mathrm{C}^{(1)}$ & $16 / 8 \mathrm{~h}$ & - & 4 & + & + & - & - & - \\
\hline Komulainen et al. 1994 & Jun & $(++) 10$ & $25^{\circ} \mathrm{C}$ & - & + & $>10^{(2)}$ & + & - & - & - & - \\
\hline Milberg 1995 & May & (?) 8 & $20 / 8^{\circ} \mathrm{C}^{(1)}$ & $16 / 8 \mathrm{~h}$ & - & $12^{(2)}$ & + & $?$ & $?$ & $?$ & $?$ \\
\hline Miller \& Cummins 2003 & Jul, Aug & $(++) 5$ & $6-25{ }^{\circ} \mathrm{C}^{(1)}$ & $12 / 12 \mathrm{~h}$ & - & 12.5 & + & - & - & - & - \\
\hline Mitschell et al. 1998 & Feb & (?) 6.3 & polyethylene tunnel & - & - & $15^{(2)}$ & + & - & - & - & - \\
\hline Staaf et al. 1987 & Apr & $(+) 5$ & $\begin{array}{l}\text { unheated glasshouse } \\
\left(10-30^{\circ} \mathrm{C}\right)\end{array}$ & - & - & 3 & + & - & + & - & - \\
\hline Thompson \& Grime 1979 & $\begin{array}{l}\text { Oct-Oct } \\
\text { (every } 6 \\
\text { weeks) }\end{array}$ & $(++) 3$ & $20 / 15^{\circ} \mathrm{C}$ & $16 / 8 \mathrm{~h}$ & - & 1.25 & - & - & - & - & - \\
\hline Warr et al. 1994 & May, Jun & (?) 15 & shade tunnel & - & - & $10-12$ & + & - & - & - & - \\
\hline
\end{tabular}

tion patterns, influenced by soil and climate conditions, and the individual fitness of seed trees (Sarvas 1952, Bjorkbom 1967, Holm 1994, Osumi \& Sakurai 1997, Sperens 1997, Hynynen et al. 2010). The germination percentage of the seeds also varies from year to year, with mast years usually characterized by the highest germination rates (Sarvas 1952, Bjorkbom 1967, Holm 1994, Osumi \& Sakurai 1997, Sperens 1997, Raspé et al. 2000, Hynynen et al. 2010). However, pioneer tree species exhibit seed morphologies, seed dispersal distances as well as requirements for germination and seedling establishment that are different from those of intermediate and late-successional species (McVean 1953, Atkinson 1992, Lautenschlager 1994, Worrell 1995, Raspé et al. 2000). Despite differences between their fruits and seeds, birch and alder (winged nuts), willow and poplar (catkins, seeds with pappus) and rowan (small seeds within a red fleshy fruit) can be analyzed together as each group possesses morphological similarities (McVean 1956, Perala \& Alm 1990, Worrell 1995, Raspé et al. 2000).

Birches can produce 2-10 million winged seeds per tree (Perala \& Alm 1990, Huth 2009), which are 1.5-2.0 $\mathrm{mm}$ in size without the wings (Brouwer \& Stählin 1975). Seed rain takes place mainly from June to November (Perala \& Alm 1990, Huth 2009). 


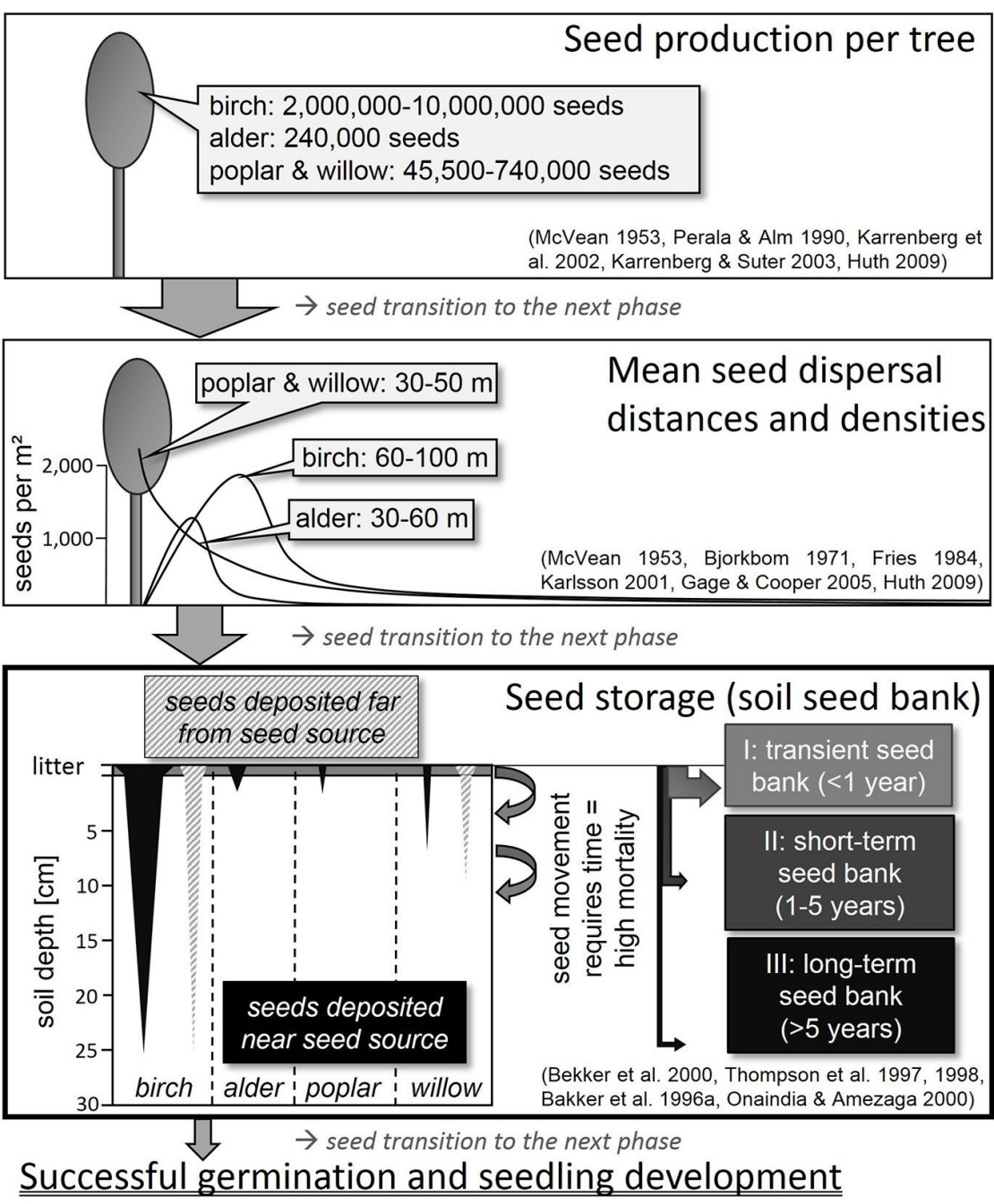

Fig. 2 - Schematic diagram showing the relation between seed production, seed dispersal and seed storage in soil of birch, alder, poplar and willow.

From November until the end of the following June, the seed rain falls to less than 100 seeds per $\mathrm{m}^{2}$ (Huth 2009). Mean dispersal distances by wind vary between 60 and $100 \mathrm{~m}$ (Fries 1984 cited in Perala \& Alm 1990, Karlsson 2001, Huth 2009), but the highest seed densities are deposited within distances of 25-50 m (Bjorkbom 1971, Fries 1984 cited in Perala \& Alm 1990 - Fig. 2). Maximum propagation distances amount to $550-800 \mathrm{~m}$ (Huth 2009). Most seeds germinate in spring after dispersal (Perala \& Alm 1990). Alder seed trees generally produce lower seed numbers (240,000 seeds per tree) than birch. The diaspores of alder have smaller wings and larger seed nuts (2.0-2.5 mm), and their mean and maximum dispersal distances from seed trees are $30 \mathrm{~m}$ and $60 \mathrm{~m}$, respectively (McVean 1953, Brouwer \& Stählin 1975). High seed densities were found within distances of less than $10 \mathrm{~m}$ (McVean 1953, 1956, Karlsson 2001). Seeds of alder trees are mature in November, but most are only released in February and March, and, like birch, germinate predominantly after dispersal in spring (Pietzarka \& Roloff 2010). Seeds of birch and alder do not exhibit dormancy
(McVean 1953, Atkinson 1992). The spatial distribution of deposited seeds on soil depends on the position of the seed trees and on the dispersal agents (Bakker et al. 1996b). The distribution of wind-dispersed seeds tends to be non-random (Greene \& Johnson 1996). This applies especially to birch and alder but also to willow and poplar. Deposited seeds of these species are often spatially aggregated because the seeds are brought in dense infructescenses (Hill \& Stevens 1981, Kjellsson 1992, Dougall \& Dodd 1997).

Willows and poplars can produce between 45,500 and 740,000 seeds per tree (Karrenberg et al. 2002, Karrenberg \& Suter 2003). The wind-dispersed (anemochorous) willow and poplar seeds possess hairs to facilitate flight and range in size between 0.8-1.5 mm and 1.0-2.5 mm, respectively (Brouwer \& Stählin 1975). Maximum willow seed dispersal distances of $2-3 \mathrm{~km}$ are much longer than for birch and alder (Schirmer 2006). For this reason, Gage \& Cooper (2005) always adopted a background level (i.e., "noise") of 10-30 seeds per $\mathrm{m}^{2}$. Nevertheless, the largest densities of deposited seeds were measured at dis- tances of between 30-50 $\mathrm{m}$ from willow seed trees (Gage \& Cooper 2005 - Fig. 2). The small seeds of both genera are shortlived (Worrell 1995, Barsoum 2002, Young \& Clements 2003). Regarding early flowering (spring) poplars and willow species, like Salix caprea L., seed rain takes place from April to June (Chmelar \& Meusel 1986). Seeds lying on soil that do not germinate immediately after dispersal lose their viability after 1-6 weeks (Junttila 1976, Niiyama 1990, Leder 1992, Worrell 1995, Karrenberg \& Suter 2003). In contrast, seeds of late flowering (summer and autumn) willow species remain viable until the next spring (Chmelar \& Meusel 1986), which means a lifespan of about half a year.

The fruits of rowan ripen between August and October (Raspé et al. 2000). Fruits and seeds are dispersed endozoochorously, by birds and small mammals. The seeds of rowan exhibit embryo and seed coat dormancy. If rowan fruits are not eaten by animals, the seeds germinate in the second year after maturation, when embryo and seed coat dormancy is broken under natural conditions (Raspé et al. 2000). Sometimes the seeds undergo a second period of dormancy when temperatures rise above $10{ }^{\circ} \mathrm{C}$ after winter or cold storage (Spethmann 2000). In such cases, seeds can remain viable for up to 5 years in the soil (Erlbeck 1998). Birds, as the main consumer of rowan fruits, have a significant influence on the spatial patterns of seed distribution. Bird droppings were mostly found under trees in more or less closed forests, and only very rarely in large gaps or open areas lacking structural complexity (Zywiec \& Ledwon 2008). Structural elements are used as perches by birds (McDonnell \& Stiles 1983). Most frequently, birds drop seeds up to $40 \mathrm{~m}$ from seed trees (Zywiec et al. 2013). In the case of endozoochory, the density patterns of rowan seeds in the soil are clumped rather than randomly distributed (Clark et al. 1998, Zywiec et al. 2013).

\section{Characterization and classification of soil seed banks}

Simpson et al. (1989) emphasized that, "all viable seeds present on or in soil or associated litter constitute the soil seed bank." Seeds buried in the upper soil layer (litter and humus layer) have in most cases only been part of the seed bank for a short time. These seeds are probably part of the last seed rain, thus the character of the seed bank in the upper soil is prevailingly transient (Graber \& Thompson 1978, Bakker et al. 1996a, 1996b, Osumi \& Sakurai 1997, Houle 1998, Heinrichs 2010). Given the species-specific timing of seed rain, the time of sampling represents an important piece of information for the interpretation of seed densities in transient seed banks. Seeds found in deeper mineral soil layers are older and have persisted in the soil for a longer period (Kjellsson 1992, Bakker et al. 1996b, Thompson et al. 1997). There- 
fore, information on seed depth can be used as an indirect method to determine the seed longevity in the soil of a particular tree species. Buried seed experiments have contributed to a better understanding of the duration of seed viability in deeper soil layers. The experiments demonstrated what might happen to seeds in relation to viability, decomposition and mortality over time during storage in soil (Granström 1987, Skoglund \& Verwijst 1989).

Litter cover and litter thickness are also two very important factors. Thick litter protects deposited seeds against movement, drought, predation and early germination, and so may help to maintain higher viability (Granström \& Fries 1985, Egawa \& Tsuyuzaki 2013). Almost no viable seeds were found on sites without litter protection. Thin litter, including seeds, for example, will be carried away by wind and accumulated at other places (Egawa \& Tsuyuzaki 2013). Independent of the species, the number of viable seeds on and in peatland increased with litter thickness. The thickness of the humus layer determines the period of time required by seeds to penetrate litter and humus. During this time seeds are subject to mortality (Sarvas 1952, Van Tooren 1988, Holm 1994). Small, light and dry seeds without pulp are less prone to predation than larger seeds (Leck et al. 1989). Findings of glass bead experiments (the size and weight of the beads corresponded to rowan fruits) revealed that $30-$ $40 \%$ of all glass beads moved $1 \mathrm{~cm}$ in the soil over a 6-month period, whereas $4 \%$ were transported 2-5 cm (Van Tooren 1988, Burmeier et al. 2010). Small seeds pass through litter faster, reaching the humus and mineral soil layer in a shorter time than larger seeds or beads (Egawa \& Tsuyuzaki 2013). This is an advantage for pioneer tree species with regard to their strategy of fast colonization of disturbed areas: the small, light and dry seeds without pulp (Leck et al. 1989) achieve quicker contact with the mineral soil and can germinate successfully.

Soil seed banks can generally be classified according to the seed longevity of the species; that is, the period of time for which a seed stays viable and capable of germination. The classification most widely applied is that described by Thompson et al. (1997, 1998), who differentiated four types. The first type (I) includes all species with transient seed banks with a persistence in the soil of less than 1 year. Species with shortterm persistent seeds (1-5 years) are assigned to type II. Type III is as a long-term persistent seed bank and includes species with seeds that persist in the soil for at least 4-5 years. Species that cannot be assigned to any seed bank type are combined in type IV.

\section{Soil seed bank of Betula spp.}

Houle (1998) found that birch seeds are viable for less than 2-3 years under field conditions, due to multiple causes of mor- tality. Mortality rose to $99 \%$ under certain climate conditions (Houle 1998). However, $50-80 \%$ of birch seeds buried artificially in soil were still viable after 3-5 years of storage (Granström 1987, Skoglund \& Verwijst 1989). After 5 years stored birch seeds were partly degraded, but 50-60\% remained viable (Granström 1987). It is assumed that birch seeds decompose within a period of 5-7 years (Sarvas 1952). Skoglund \& Verwijst (1989) concluded that, at a depth of $10 \mathrm{~cm}$, birch seeds buried in the soil have a theoretical half-life in forest soil of roughly 13 years, but less than 1 year in the soil of wet meadows. In wet soils, early germination and fungal attacks lead to higher mortality rates (Harper 1955 cited in Ludwig et al. 1957). Birch seeds sown on bare ground germinated in the first year (Miles 1974). Therefore, seeds found in deeper mineral soil probably did not originate from the previous seed rain and so were part of the soil seed bank.

In most of the publications analyzed, birch was the only tree species exhibiting a high degree of consistency in soil seed banks in central and north-west European temperate forests ( $83 \%$ of sample plots). Often birch was the second most abundant species of all, including herbaceous plant species. However, some authors found the extent of birch seed in the soil to be negligible (Hill \& Stevens 1981, Staaf et al. 1987, Buckley et al. 1997). Betula species were present in all kinds of forest type, but seed densities depended on the presence or absence of seed sources. Large numbers of seeds can be found in the soil in the vicinity of seed trees (Bossuyt \& Hermy 2001 - Fig. 2). Birch seed density ranged from 1 to 1100 seeds per $\mathrm{m}^{2}$ in coniferous stands, mostly spruce and pine forests (Granström 1982, Komulainen et al. 1994, Warr et al. 1994, Dougall \& Dodd 1997, Augusto et al. 2001, Miller \& Cummins 2003, Berger et al. 2004, Heinrichs 2010, Jaroszewicz 2013). In deciduous forests 7-3850 viable seeds per $\mathrm{m}^{2}$ were detected (Staaf et al. 1987, Kjellsson 1992, Warr et al. 1994, Dougall \& Dodd 1997, Jankowska-Blaszczuk et al. 1998, Augusto et al. 2001, Bossuyt et al. 2002, Miller \& Cummins 2003, Decocq et al. 2004, Jedrzejczak 2013). The seed density on succession sites ranged from 6 seeds per $\mathrm{m}^{2}$ in a 4-year old Norway spruce clear cut (Heinrichs 2010) to a maximum of 3120 seeds per $\mathrm{m}^{2}$ in a long-term overgrown grassland (Kalamees \& Zobel 1998). Highest densities of 70-3760 seeds per $\mathrm{m}^{2}$ were found in pure or birch-dominated stands (Hester et al. 1991, Kjellsson 1992, Warr et al. 1994, Jankowska-Blaszczuk 1998, Kalamees \& Zobel 1998, Mitschell et al. 1998, Falinska 1999, Miller \& Cummins 2003, Dölle \& Schmidt 2009). However, o to 144 viable seeds per $\mathrm{m}^{2}$ were detected in soils of deciduous and coniferous forests without any mature trees or seedlings in the proximity (Granström 1982, Staaf et al. 1987, Amrein et al. 2005). Hill \& Stevens (1981) detected more viable birch seeds in a 4-year-old clear cut of a former Douglas fir plantation than seedlings in the vegetation layer, an indication that birch seeds remain viable in the soil for a longer time than is frequently assumed.

The birch seed density in different soil layers was reported for only a few samples. Various authors mentioned that birch seeds are mostly found in the humus or uppermost soil layers (Hill 1979, Granström 1988, Houle 1998, Sullivan \& Ellison 2006). Houle (1998) concluded that less than $2 \%$ of birch seed rain reaches the persistent seed bank. The numbers of birch seeds found at different soil depths ranged from $1-188$ seeds per $m^{2}$ in the litter and humus layer (Granström 1982, Staaf et al. 1987) to $1-80$ seeds per $m^{2}$ at a depth of $0-5 \mathrm{~cm}$ in mineral soil, independent of seed source presence or absence (Granström 1982, Staaf et al. 1987, Augusto et al. 2001, Jaroszewicz 2013). In samples taken at a depth of $5-10 \mathrm{~cm}$ in deciduous and coniferous forests 3 and 71 birch seeds per $\mathrm{m}^{2}$ were detected (Jaroszewicz 2013, Jedrzejczak 2013). Regardless of the occurrence of seed trees, an average of 33 seeds per $\mathrm{m}^{2}$ were present in the mineral soil down to a depth of 10-20 cm (Bossuyt et al. 2002), which may lead one to assume that birch seeds live longer in the soil than is often assumed (Fig. 2). With increasing soil depth, the number of viable birch seeds declined, but remained high enough for reforestation. On succession sites, where many seed sources are available for seed supply, 324 seeds per $\mathrm{m}^{2}$ were recorded in the humus and litter layer (Hill \& Stevens 1981). At depths of $0-5 \mathrm{~cm}$ and $5-10 \mathrm{~cm}$ in the mineral soils of these sites, densities reached 792880 seeds per $\mathrm{m}^{2}$, and $20-880$ seeds per $\mathrm{m}^{2}$, respectively (Hill \& Stevens 1981, Bakker et al. 1996a, Kalamees \& Zobel 1998).

Irrespective of the timing during the year of soil sample collection, high densities of viable birch seeds could always be found. Highest seed densities of 20-3850 viable birch seeds per $\mathrm{m}^{2}$ occur in the period from May to June (Warr et al. 1994). The results of the studies showed that seed densities were more dependent on the presence or absence of seed sources than on the timing of soil sampling or on the forest community of the sampling site (Kjellsson 1992, Houle 1998, Bossuyt \& Hermy 2001).

The different studies, and the different assessments of birch seed longevity, explained the varying assignments of birch to the contrasting soil seed bank types, which ranged from purely transient (Bekker et al. 2000), through transient/short-term persistent (Thompson et al. 1997) to shortterm/long-term persistent (Bakker et al. 1996a). The assumption made by Olmsted \& Curtis (1947), Bakker et al. (1996b) and Graber \& Thompson (1978) that seed rain from outside of a stand is necessary for the regeneration of the species where birch seed trees are not present on a site, due to an insufficient seed bank, cannot be supported without new research. 


\section{Soil seed bank of Alnus glutinosa (L.)}

Gaertn.

Viable alder seeds were detected in the soil seed bank less often than birch seeds ( $10 \%$ of sample plots). This is probably due to the lower frequency of alder trees than birch in European managed forests. Seeds were only found in soils where there were seed sources close by (Kjellsson 1992, Falinska 1999, Decocq et al. 2004 - Fig. 2). Alder seeds were mainly detected on meadow and hayfield succession sites aged between 0-25 years. The seed density ranged between 8 and 216 seeds per $\mathrm{m}^{2}$. The maximum was found in a 20-year-old dry hayfield. In contrast to this, the maximum number recorded on a wet hayfield succession site was only 80 seeds per $\mathrm{m}^{2}$ (Bekker et al. 2000). In 40- to 175-year-old deciduous forests, 2-7 alder seeds per $\mathrm{m}^{2}$ were observed (Kjellsson 1992, Decocq et al. 2004). The highest alder seed density recorded in humus and mineral soil was 354 seeds per $\mathrm{m}^{2}$, which was obtained from a mixed limealder-birch forest (Kjellsson 1992). No alder seeds were detected in coniferous or mixed stands. The studies presenting the findings from such stands provided no information about the presence of alder seed trees or woodlands, in contrast to soil seed bank studies undertaken in deciduous stands or on succession sites. Apart from the study by Decocq et al. (2004), no viable alder seeds were found in soil samples taken between May and December; not even from samples taken next to alder seed trees (Kalamees \& Zobel 1998, Warr et al. 1994). This is a clear indication of a transient seed bank.

The number of alder seeds transported vertically in the soil, and the depth of transport, could not be derived in any detail from the studies evaluated. Kalamees \& Zobel (1998), who collected samples without litter from a pioneer forest with alder and birch, detected high numbers of viable birch seeds but no viable alder seeds. Only in one case very low densities of 2.4 and 3.2 viable alder seeds per $\mathrm{m}^{2}$ were confirmed in two mineral soil samples taken close to seed trees in June (Decocq et al. 2004). However, studies providing the occurrence of alder seeds in the soil indicated that they tend to be more prevalent in the upper soil and in the humus layer than in the lower soil layers (Fig. 2). Kjellsson (1992) concluded, therefore, that alder seeds are short-lived and that large seed numbers in the soil were probably due to recent seed rain.

The buried seed experiment by Granström (1987) indicated a shorter lifespan of alder seeds than for birch. Early germination in the field before sampling could not be ruled out, but after 1.5 years of seed storage in soil the proportion of viable seeds was about $60 \%$, and only $2 \%$ after 5 years. Interestingly, the pericarp and wings of buried alder seeds were still intact, while parts of birch seeds had begun to decompose (Granström 1987). It seems unlikely that after a long period of vertical drift many alder seeds reach the deeper soil layers in a condition allowing for germination. Decocq et al. (2004) claimed that alder can establish a more persistent seed bank, whereas Thompson et al. (1997), Bekker et al. (2000) and Onaindia \& Amezaga (2000) assigned alder to the transient seed bank type. Considering the lack of available data and literature, a reliable statement on the alder soil seed bank type is not possible. Some results suggested a transient seed bank, but this seems to have been influenced in part by peculiarities of the sites in question. In future research, typical alder sites such as floodplains should be included in sampling.

\section{Soil seed banks of Salix spp. and Populus tremula $L$.}

The results provided on Salix spp. were often no more specific than a mere reference to the genus "willow". Therefore, it is not possible to discuss different willow species in detail. Despite the common assumption that willows have short-lived seeds (Junttila 1976, Niiyama 1990, Barsoum 2002, Young \& Clements 2003), the genus was the second most abundant pioneer tree species in the papers analyzed, occurring in $17 \%$ of all sample plots. Poplar seeds, morphologically similar to willow seeds, were almost always absent in soil seed banks ( $1 \%$ of sample plots). Three European aspen seeds per $\mathrm{m}^{2}$ were observed only once by Heinrichs (2010) on a succession site, which indicates a rapid loss of poplar seed viability in soil (Worrell 1995, Barsoum 2002).

Viable willow seeds germinated predominantly in soil samples from succession sites, where seed trees were present. The highest recorded number of willow seeds was 350 seeds per $\mathrm{m}^{2}$ on a 15-year-old meadow succession site dominated by willow (Falinska 1999). Summarizing all succession studies, seed density ranged from 6 to 350 seeds per $\mathrm{m}^{2}$ (Bakker et al. 1996a, Falinska 1999, Bekker et al. 2000, Dölle \& Schmidt 2009). A few willow seeds were also present in some soil samples from beech forests, with 7 and 28 seeds per $\mathrm{m}^{2}$ (Staaf et al. 1987), in Norway spruce forests with 11 and 104 seeds per $\mathrm{m}^{2}$ (Granström 1988, Berger et al. 2004), and in 65year old mixed beech-spruce forest with $156 \mathrm{~S}$. caprea seeds per $\mathrm{m}^{2}$ (Berger et al. 2004). All of these authors studied the humus and mineral soil layers. In one study, $S$. alba L. grew at high frequencies in the vegetation (7-24\%), but no viable seeds were identified in the soil (Bissels et al. 2005). Gurnell et al. (2006) also detected willow species in the vegetation along a newly created riverbank but not in the seed bank. The authors explained the results by assuming transience of the seeds and immediate germination after ground contact.

Information on willow seed densities in different soil layers and at different depths was rare in the evaluated studies. Staaf et al. (1987) observed 7-14 willow seeds per $\mathrm{m}^{2}$ in the humus layer and in the mineral soil at a depth of $0-5 \mathrm{~cm}$ in a beech forest. Bakker et al. (1996a), by contrast, recorded 80 goat willow seeds per $\mathrm{m}^{2}$ in some $0-5$ $\mathrm{cm}$ soil samples taken from 20- to 80-yearold Juniperus shrubland, whereas 80 seeds per $\mathrm{m}^{2}$ were detected in a 5-10 cm soil sample in annually grazed Juniperus shrubland. Six seeds of S. caprea were present only once in mineral soil sampled from a succession site (Dölle \& Schmidt 2009). All authors reported the absence of willow seed trees, which highlights long willow seed dispersal distances (Schirmer 2006) and the possibility of formation of a willow soil seed bank (Fig. 2). However, viable willow and poplar seeds were only derived from samples collected in March and April (Staaf et al. 1987, Granström 1988, Bakker et al. 1996a, Falinska 1999, Bekker et al. 2000, Berger et al. 2004, Dölle \& Schmidt 2009). Samples taken near willow and European aspen seed trees in May and June contained no viable seeds of either genus (Falinska 1999, Decocq et al. 2004) due to a rapid loss of germination ability after deposition on soil (Barsoum 2002). This also provides a strong indication of a transient seed bank for both genera.

Information about willow seeds artificially buried in the soil could not be found in the literature. Thompson et al. (1998) concluded that willows do not have a persistent seed bank. Certain aspen and Salix spp., especially S. caprea, an early flowering species, were assigned to the transient seed bank type (Thompson et al. 1997, 1998, Bekker et al. 2000), whereas S. alba, a late flowering willow species, was assigned to the long-term persistent seed bank category (Berger et al. 2004). Perhaps the high numbers of viable willow seeds recorded in the soil had all fallen into cracks or were from late-flowering willow species. It also seems possible that willow seeds protected by soil are viable for a longer time than those on the ground surface or humus layer, or that the movement of the smaller and lighter seeds to deeper soil layers proceeds rapidly, as documented by Van Tooren (1988) and Burmeier et al. (2010).

\section{Soil seed bank of Sorbus aucuparia L.}

In contrast to all the other pioneer tree species mentioned, rowan was not found in any of the soil seed bank studies, although seed trees were present in some of the study areas (Granström 1982, Decocq et al. 2004, Dölle \& Schmidt 2009, Heinrichs 2010, Jedrzejczak 2013). Often the only indication of successful reproduction was the presence of young rowan trees in the herb and shrub layer, for example, in conifer forests (Granström 1982, Heinrichs 2010). With secondary dormancy, the seeds can be part of the soil seed bank for at least 1-2 years (Leder 1992). However, the findings of this review indicate that rowan seeds are always absent from the soil seed bank. 
Grime et al. (1988 cited in Raspé et al. 2000) and Dölle \& Schmidt (2009) assigned rowan to the transient seed bank type, because seeds persist in soil for less than 1 year. In contrast, Hill (1979), Leder (1992) and Erlbeck (1998) agreed that rowan seeds can remain viable in the soil for long time, up to 5 years. Based on the above, it would appear possible that rowan has a short-term persistent seed bank. This assumption would seem to have been confirmed by an experiment with buried pomes, which showed that more than $80-$ $90 \%$ of the seeds remain viable after 2 years storage in the soil. During the third year the ability to germinate decreased to 30-50\%, but some rowan seeds remained viable after 5 years of storage (Granström 1987). Up to $9 \%$ of fresh, stratified rowan seeds exposed under field conditions germinated in the second or third year after sowing (Miles 1974). Due to the clumped distribution of rowan seeds by birds (McDonnell \& Stiles 1983), future studies of the occurrence of rowan in soil seed banks should take into consideration the structural elements used as perches by birds (Tiebel et al. 2017).

\section{Conclusions}

Pioneer tree species are short-lived, light demanding species, which are very important for the successful colonization and reforestation of large disturbed woodlands in central and north-west Europe. Soil seed banks can drive reforestation in the absence of seed rain. Soil seed banks in woodlands play an important role in succession and in the regeneration of disturbed areas in European temperate forests.

This review showed that pioneer tree species do not possess the kind of longterm seed banks that certain herbaceous species can have. The findings suggest that birch is the only pioneer tree species of temperate forests in central and northwest Europe with a longer-lived soil seed bank. Often birch was the second most abundant species in soil and the only pioneer tree species with a high degree of consistency in soil seed banks. In medium to deeper soil layers $(5-10 \mathrm{~cm})$ birch seeds seem to have at least a short-term persistent seed bank. Alder seeds are poorly represented in forest soils compared to birch, so a reliable statement on alder soil seed bank type is not possible; the few results available suggest a transient seed bank. The studies for willow and poplar seeds partly confirmed the assumption of very short-lived seeds, although willow was the second most abundant pioneer tree species in soil seed banks and also found in mineral soil $(0-5 \mathrm{~cm})$. Surprisingly in the case of rowan, the only fleshy-fruited pioneer tree species with proven seed dormancy, a transient seed bank must be assumed due to the absence of rowan seeds in the soil. Buried seed experiments showed, however, that rowan seeds can build up a short-term persistent seed bank due to dormancy.

Statements on the seed densities of pioneer tree species in the soils of different coniferous and deciduous forest types cannot be given. The reason for this is that these seed densities are primarily influenced by the number of and the distance from seed sources, and the seasons of seed production and seed dispersal. Our review revealed that the successful regeneration of birch, alder and willow depends mainly on the proximity of seed trees. Therefore, the proximity of trees is important for the regeneration of species with short-lived seeds. The findings of the review also indicate a dependence between seed density in the soil and the season in which soil sampling occurs. Maximum seed densities of birch, alder and willow were detected during and shortly after seed rain. No statement can be made in this regard in relation to rowan and poplar.

This review revealed a number of open questions concerning the capacity of all European pioneer tree species to establish seed banks. These issues are connected to: (a) the seed viability under different soil conditions and litter thickness; (b) the speed of seed movement into deeper soil layers; and (c) the direct correlation between the proximity of seed trees and the resultant number of seeds in the soil. At present, it can be concluded that birch, representative of pioneer tree species in temperate forests of central and northwest Europe, has the capacity to establish a seed bank of a duration of 1-5 years, sufficient to compensate for years with lower levels of seed production and to regenerate successfully after disturbance. However, the soil seed bank must be supplemented by fresh seeds from surrounding seed trees as often as possible in order to guarantee continuous regeneration.

\section{Acknowledgements}

This review was supported financially by a scholarship provided from the Deutsche Bundesstiftung Umwelt (DBU) fund to promote young scientists. We thank the reviewers for their helpful comments and David Butler Manning for proofreading the text.

\section{References}

Amezaga I, Onaindia M (1997). The effect of evergreen and deciduous coniferous plantations on the field layer and seed bank of native woodlands. Ecography 20: 308-318. - doi: 10.1111 |j.1600-0587.1997.tbo0375.x

Amrein D, Rusterholz H-P, Baur B (2005). Disturbance of suburban Fagus forests by recreational activities: effects on soil characteristics, aboveground vegetation and seed bank. Applied Vegetation Science 8: 175-182. - doi: 10.16 58/1402-2001(2005)008[0175:DOSFFB]2.0.CO;2 Argus GW (2006). Guide to Salix (willow) in the Canadian Maritime Provinces (New Brunswick, Nova Scotia, and Prince Edward Island). Canadian Museum of Nature, Ottawa, Canada, pp.
49. [online] URL: http://accs.uaa.alaska.edu/fil es/botany/publications/2006/GuideSalixCanadia nAtlanticMaritime.pdf

Atkinson MD (1992). Betula pendula Roth (B. verrucosa Ehrh.) and B. pubescens Ehrh. Journal of Ecology 80: 837-870. - doi: 10.2307/2260870 Augusto L, Dupouey J-L, Picard J-F, Ranger J (2001). Potential contribution of the seed bank in coniferous plantations to the restoration of native deciduous forest vegetation. Acta Oecologica 22: 87-98. - doi: 10.1016/S1146-609X(01) 01104-3

Bakker JP, Bakker ES, Rosén E, Verwej GL, Bekker RM (1996a). Soil seed bank composition along a gradient from dry alvar grassland to Juniperus shrubland. Journal of Vegetation Science 7: 165-176. - doi: 10.2307/3236316

Bakker JP, Poschlod P, Strykstra RJ, Bekker RM, Thompson K (1996b). Seed banks and seed dispersal: important topics in restoration ecology. Acta Botanica Neerlandica 45: 461-490. - doi: 10.1111/j.1438-8677.1996.tboo806.x

Barnes BV, Zak DR, Denton SR, Spurr SH (1998). Forest ecology. John Wiley and Sons, New York, USA, pp. 774.

Barsoum N (2002). Relative contributions of sexual and asexual regeneration strategies in Populus nigra and Salix alba during the first years of establishment on a braided gravel bed river. Evolutionary Ecology 15: 255-279. - doi: 10.1023/ A:1016028730129

Bekker RM, Verwej GL, Bakker JP, Fresco LFM (2000). Soil seed bank dynamics in hayfield succession. Journal of Ecology 88: 594-607. - doi: 10.1046/j.1365-2745.2000.00485.x

Berger TW, Sun B, Glatzel G (2004). Soil seed banks of pure spruce (Picea abies) and adjacent mixed species stands. Plant and Soil 264: 53-67. - doi: 10.1023/B:PLSO.0000047753.36424.41

Bissels S, Donath TW, Hölzel N, Otte A (2005). Ephemeral wetland vegetation in irregularly flooded arable fields along the northern Upper Rhine: the importance of persistent seedbanks. Phytocoenologia 35: 469-488. - doi: 10.1127/03 40-269X/2005/0035-0469

Bjorkbom JC (1967). Seedbed-preparation methods for paper birch. Research Paper NE-209, Northeastern Forest Experiment Station, USDA Forest Service, Upper Darby, USA, pp. 15.

Bjorkbom JC (1971). Production and germination of paper birch seed and its dispersal into a forest opening. Research Paper NE-209, Northeastern Forest Experiment Station, USDA Forest Service, Upper Darby, USA, pp. 15.

Bossuyt B, Hermy M (2001). Influence of land use history on seed banks in European temperate forest ecosystems: a review. Ecography 24: 225238. - doi: 10.1034/j.1600-0587.2001.240213.x

Bossuyt B, Heyn M, Hermy M (2002). Seed bank and vegetation composition of forest stands of varying age in central Belgium: consequences for regeneration of ancient forest vegetation. Plant Ecology 162: 33-48. - doi: 10.1023/A:10203 91430072

Bossuyt B, Honnay O (2008). Can the seed bank be used for ecological restoration? An overview of seed bank characteristics in European communities. Journal of Vegetation Science 19: 875884. - doi: 10.3170/2008-8-18462

Bradbeer JW (1988). Seed dormancy and germination. Blackie and Son Ltd., Glasgow and Lon- 
don, UK, pp. 146.

Brouwer W, Stählin A (1975). Handbuch der Samenkunde für Landwirtschaft, Gartenbau und Forstwirtschaft [Seed manual of agriculture, horticulture and forestry]. DLG-VerlagsGmbH, Frankfurt am Main, Germany, pp. 655. [in German]

Brown AHF, Oosterhuis L (1981). The role of buried seed in coppicewood. Biological Conservation 21: 19-38. - doi: 10.1016/0006-3207(81) 90066-5

Buckley GP, Howell R, Anderson MA (1997). Vegetation succession following ride edge management in lowland plantations and woods. 2. The seed bank resource. Biological Conservation 82: 305-316. - doi: 10.1016/Sooo6-3207(97) 00025-6

Burmeier S, Eckstein RL, Otte A, Donath TW (2010). Desiccation cracks act as natural seed traps in flood-meadow systems. Plant and Soil 333: 351-364. - doi: 10.1007/s11104-010-0350-1 Chmelar J, Meusel W (1986). Die Weiden Europas [Willows of Europe]. A. Ziemsen Verlag, Wittenberg, Germany, pp. 144. [in German] Clark JS, Macklin E, Wood L (1998). Stages and spatial scales of recruitment limitation in southern Appalachian forests. Ecological Monographs 68: 213-235. - doi: 10.1890/0012-9615(19 98)068[0213:SASSOR]2.0.CO;2

Decocq $G$, Valentin B, Toussaint B, Hendoux F, Saguez R, Bardat J (2004). Soil seed bank composition and diversity in a managed temperate deciduous forest. Biodiversity and Conservation 13: 2485-2509. - doi: 10.1023/B:BIOC.000004 8454.08438.c6

Dölle M, Schmidt W (2009). The relationship between soil seed bank, above-ground vegetation and disturbance intensity on old-field successional permanent plots. Applied Vegetation Science 12: 415-428. - doi: 10.1111/j.1654-109X.20 09.01036.x

Donelan M, Thompson K (1980). Distribution of buried viable seeds along a successional series. Biological Conservation 17: 297-311. - doi: 10.1016 10006-3207(80)90029-4

Dougall TAG, Dodd JC (1997). A study of species richness and diversity in seed banks and its use for the environmental mitigation of a proposed holiday village development in a coniferized woodland in south east England. Biodiversity and Conservation 6: 1413-1428. - doi: 10.1023/A: 1018345915418

Ebrecht L, Schmidt W (2008). Bedeutung der Bodensamenbank und des Diasporentransports durch Forstmaschinen für die Entwicklung der Vegetation auf Rückegassen [Impact of soil seed bank and diaspore transportation by forest machines on the development of vegetation along skid trails]. Forstarchiv 79: 91-105. [in German]

Egawa C, Tsuyuzaki S (2013). The effects of litter accumulation through succession on seed bank formation for small and large seeded species. Journal of Vegetation Science 24: 1062-1073. doi: $10.1111 /$ jvs.12037

Erlbeck R (1998). Die Vogelbeere (Sorbus aucuparia) - ein Porträt des Baumes des Jahres 1997 [Rowan (Sorbus aucuparia) - a portrait of the tree of the year 1997]. In: "Beiträge zur Vogelbeere" [Article about rowan] (Schmidt O ed.). Berichte aus der Bayrischen Landesanstalt für
Wald und Forstwirtschaft 17: pp. 2-14. [in German]

Falinska K (1999). Seed bank dynamics in abandoned meadows during a 20-year period in the Bialowieza National Park. Journal of Ecology 87: 461-475. - doi: 10.1046/j.1365-2745.1999.003 64.x

Fenner M (1985). Seed ecology. Chapman and Hall Ltd, London and New York, UK and USA, pp. 151.

Fischer H, Huth F, Hagemann U, Wagner S (2016). Developing restoration strategies for temperate forests using natural regeneration processes. In: "Restoration of boreal and temperate forests" (Stanturf JA ed.). CRC Press, Boca Raton, USA, pp. 103-164.

Gage EA, Cooper DJ (2005). Patterns of willow seed dispersal, seed entrapment, and seedling establishment in a heavily browsed montane riparian ecosystem. Canadian Journal of Botany 83: 678-687. - doi: 10.1139/B05-042

Godefroid S, Phartyal SS, Koedam N (2006). Depth distribution and composition of seed banks under different tree layers in a managed temperate forest ecosystem. Acta Oecologica 29: 283-292. - doi: 10.1016/j.actao.2005.11.005

Graber RE, Thompson DF (1978). Seeds in the organic layers and soil of four beech-birchmaple stands. Research Paper NE-401, Northeastern Forest Experiment Station, USDA Forest Service, Broomall, USA, pp. 10. [online] URL: http://www.fs.fed.us/ne/newtown_squa re/publications/research_papers/pdfs/scanned/ OCR/ne_rp401.pdf

Grandin U (2001). Short-term and long-term variation in seed bank/vegetation relations along an environmental and successional gradient. Ecography 24: 731-741. - doi: 10.1111/j.1600-0587. 2001.tboo534.x

Granström A (1982). Seed banks in five boreal forest stands originating between 1810 and 1963. Canadian Journal of Botany 60: 1815-1821. doi: 10.1139/b82-228

Granström A, Fries C (1985). Depletion of viable seeds of Betula pubescens and Betula verrucosa sown onto some north Swedish forest soils. Canadian Journal of Forest Research 15: 11761180. - doi: 10.1139/x85-191

Granström A (1987). Seed viability of fourteen species during five years of storage in a forest soil. Journal of Ecology 75: 321-331. - doi: 10.230 7/2260421

Granström A (1988). Seed banks at six open and afforested heathland sites in southern Sweden. Journal of Applied Ecology 25: 297-306. - doi: $10.2307 / 2403627$

Greene DF, Johnson EA (1996). Wind dispersal of seeds from a forest into a clearing. Ecology 77 : 595-609. - doi: 10.2307/2265633

Gurnell AM, Boitsidis AJ, Thompson K, Clifford NJ (2006). Seed bank, seed dispersal and vegetation cover: Colonization along a newly-created river channel. Journal of Vegetation Science 17: 665-674. - doi: 10.1111/j.1654-1103.2006. tbo2490.x

Heinrichs S (2010). Response of the understorey vegetation to select cutting and clear cutting in the initial phase of Norway spruce conservation. PhD thesis, Faculty of Mathematics and Natural Sciences, Georg-August-University Göttingen, Göttingen, Germany, pp. 177. [online]
URL: http://ediss.uni-goettingen.de/handle/118 58/00-1735-0000-0006-B691-E

Hester AJ, Gimingham CH, Miles J (1991). Succession from heather moorland to birch woodland. III. Seed availability, germination and early growth. Journal of Ecology 79: 329-344. - doi: $10.2307 / 2260716$

Hill MO (1979). The development of a flora in even-aged plantations. In: "The ecology of even-aged forest plantations" (Ford ED, Malcolm DC, Atterson J eds). Institute of Terrestrial Ecology, Cambridge, UK, pp. 175-192. [online] URL: http://nora.nerc.ac.uk/id/eprint/7075/1/No 07075CP.pdf

Hill MO, Stevens PA (1981). The density of viable seed in soils of forest plantations in upland Britain. Journal of Ecology 69: 693-709. - doi: $10.2307 / 2259692$

Holm SO (1994). Reproductive patterns of Betula pendula and B. pubescens coll. along a regional altitudinal gradient in northern Sweden. Ecography 17: 60-72. - doi: 10.1111/j.1600-05 87.1994.tbooo77.x

Hopfensperger KN (2007). A review of similarity between seed bank and standing vegetation across ecosystems. Oikos 116: 1438-1448. - doi: 10.1111/j.2007.0030-1299.15818.x

Houle G (1998). Seed dispersal and seedling recruitment of Betula alleghaniensis: spatial inconsistency in time. Ecology 79: 807-818. - doi: 10.1890/0012-9658(1998)079[0807:SDASRO]2.0 .CO;2

Huth F (2009). Untersuchungen zur Verjüngungsökologie der Sand-Birke (Betula pendula Roth) [Study of regeneration cycle of sand birch (Betula pendula Roth)]. PhD thesis, Faculty of Forest, Geo and Hydro, Dresden University of Technology, Dresden, Germany, pp. 383. [in German]

Hynynen J, Niemistö P, Viherä-Aarnio A, Brunner A, Hein S, Velling P (2010). Silviculture of birch (Betula pendula Roth and Betula pubescens Ehrh.) in northern Europe. Forestry 83: 103-119. - doi: 10.1093/forestry/cppo35

Jankowska-Blaszczuk M (1998). Variability of the soil seed banks in the natural deciduous forest in the Bialowieza National Park. Acta Societatis Botanicorum Poloniae 67: 313-324. - doi: 10.558 6/asbp.1998.040

Jankowska-Blaszczuk M, Kwiatkowska AJ, Panufnik D, Tanner E (1998). The size and diversity of the soil seed banks and the light requirements of the species in sunny and shady natural communities of the Bialowieza Primeval Forest. Plant Ecology 136: 105-118. - doi: 10.1023/A: 1009750201803

Jaroszewicz B (2013). Endozoochory by European bison influences the build-up of the soil seed bank in subcontinental coniferous forest. European Journal of Forest Research 132: 445 452. - doi: 10.1007/s10342-013-0683-4

Jedrzejczak E (2013). Soil seed bank in selected patches of vegetation in the beech forest of Beskid Åšlaski (southern Poland). Casopis Slezského Zemského Muzea 62: 137-150. - doi: 10.2478/cszma-2013-0015

Junttila O (1976). Seed germination and viability in five Salix species. Astarte 9: 19-24.

Kalamees R, Zobel M (1998). Soil seed bank composition in different successional stages of a species rich wooded meadow in Laelatu, west- 
ern Estonia. Acta Oecologica 19: 175-180. - doi: 10.1016/S1146-609X(98)80021-0

Karlsson M (2001). Natural regeneration of broadleaved tree species in southern Sweden Effects of silvicultural treatments and seed dispersal from surrounding stands. PhD thesis, Southern Swedish Forest Research Centre, Swedish University of Agricultural Sciences, Alnarp, Sweden, pp. 44. [online] URL: http:// pub.epsilon.slu.se/42/

Karrenberg S, Kollmann J, Edwards PJ (2002). Pollen vectors and inflorescence morphology in four species of Salix. Plant Systematics and Evolution 235: 181-188. - doi: 10.1007/s00606$002-0231-z$

Karrenberg S, Suter M (2003). Phenotypic tradeoffs in the sexual reproduction of Salicaceae from flood plain. American Journal of Botany 90: 749-754. - doi: 10.3732/ajb.90.5.749

Kjellsson G (1992). Seed banks in Danish deciduous forests: species composition, seed influx and distribution pattern in soil. Ecography 15: 86-100. - doi: 10.1111/j.1600-0587.1992.tboo012.x Komulainen M, Vieno M, Yarmishko VT, Daletskaja TD, Maznaja EA (1994). Seedling estab lishment from seeds and seed banks in forests under long-term pollution stress: a potential for vegetation recovery. Canadian Journal of Botany 72: 143-149. - doi: 10.1139/b94-019

Lautenschlager D (1994). Die Weiden von Mittelund Nordeuropa [The willowe of central and northern Europe]. Birkhäuser Verlag, Basel, Switzerland, pp. 171. [in German]

Leck MA, Parker VT, Simpson RL (1989). Ecology of soil seed banks. Academic Press Limited, London, UK, pp. 462.

Leck MA, Parker VT, Simpson RL (2008). Seedling ecology and evolution. University Press, Cambridge, UK, pp. 514. [online] URL: http:// books.google.com/books?id=IPSYJWMHanAC

Leder B (1992). Weichlaubhölzer: Verjüngungsökologie, Jugendwachstum und Bedeutung in Jungbeständen der Hauptbaumarten Buche und Eiche [Pioneer tree species: regeneration, youth growth and importance in young stands of the main tree species beech and oak]. Landesanstalt für Forstwirtschaft Nordrhein-Westfalen, Arnsberg, Germany, pp. 416. [in German] Ludwig JW, Bunting ES, Harper JL (1957). The influence of environment on seed and seedling mortality: III. The influence of aspect on maize germination. Journal of Ecology 45: 205-224. doi: $10.2307 / 2257085$

McDonnell MJ, Stiles EW (1983). The structural complexity of old field vegetation and the recruitment of bird-dispersed plant species. Oecologia 56: 109-116. - doi: 10.1007/BF003782 25

McVean DN (1953). Alnus glutinosa (L.) Gaertn. Journal of Ecology 41: 447-466. - doi: 10.2307/ 2257070

McVean DN (1956). Ecology of Alnus glutinosa (L.) Gaertn.: VI. Post-glacial history. Journal of Ecology 44: 331-333. - doi: 10.2307/2256825

Milberg P (1995). Soil seed bank after eighteen years of succession from grassland to forest. Oikos 72: 3-13. - doi: 10.2307/3546031

Miles J (1974). Experimental establishment of new species from seed in Callunetum in northeast Scotland. Journal of Ecology 62: 527-551. doi: $10.2307 / 2258997$
Miller GR, Cummins RP (2003). Soil seed banks of woodland, heathland, grassland, mire and montane communities, Cairngorm Mountains, Scotland. Plant Ecology 168: 255-266. - doi: 10.1023/A:1024464028195

Mitschell RJ, Marrs RH, Auld MHD (1998). A comparative study of the seedbanks of heathland and successional habitats in Dorset, southern England. Journal of Ecology 86: 588-596. - doi: 10.1046/j.1365-2745.1998.00281.x

Niiyama K (1990). The role of seed dispersal and seedling traits in colonization and coexistence of Salix species in a seasonally flooded habitat. Ecological Research 5: 317-331. - doi: 10.1007/BF 02347007

Olmsted NW, Curtis JD (1947). Seeds of the forest floor. Ecology 28: 49-52. - doi: 10.2307/1932 917

Onaindia M, Amezaga I (2000). Seasonal variation in the seed banks of native woodland and coniferous plantations in northern Spain. Forest Ecology and Management 126: 163-172. - doi: 10.1016/S0378-1127(99)00o99-7

Osumi K, Sakurai S (1997). Seedling emergence of Betula maximowicziana following human disturbance and the role of buried viable seeds. Forest Ecology and Management 93: 235-243. doi: 10.1016/S0378-1127(96)03963-1

Perala DA, Alm AA (1990). Reproductive ecology of birch: a review. Forest Ecology and Management 32: 1-38. - doi: 10.1016/0378-1127(90)90104J

Pietzarka U, Roloff A (2010). Alnus glutinosa (L.) Gaertn. In: "Bäume Mitteleuropas" [Trees of central Europe] (Roloff A, Weisberger H, Lang $\mathrm{U}$, Stimm B eds). Wiley-VCH Verlag $\mathrm{GmbH}$ and Co. KGaA, Weinheim, Germany, pp. 141-155. [in German]

Plue J, Verheyen K, Calster H, Marage D, Thompson K, Kalamees R, Jankowska-Blaszczuk $M$, Bossuyt B, Hermy M (2010). Seed banks of temperate deciduous forests during secondary succession. Journal of Vegetation Science 21: $965-$ 978. - doi: 10.1111/j.1654-1103.2010.01203.x

Raspé O, Findlay C, Jacquemart A-L (2000). Sorbus aucuparia L. Journal of Ecology 88: 910930. - doi: 10.1046/j.1365-2745.2000.00502.x

Rydgren K, Hestmark G, Okland RH (1998). Revegetation following experimental disturbance in a boreal old-growth Picea abies forest. Journal of Vegetation Science 9: 763-776. - doi: $10.2307 / 3237042$

Saatkamp A, Poschlod P, Venable DL (2014). The functional role of soil seed banks in natural communities. In: "Seeds: The Ecology of Regeneration in Plant Communities" (Gallagher RS ed). CAB International, Oxfordshire, UK, pp. 263-295. [online] URL: http://books.google.com /books?id=3Bb4AgAAQBAJ

Sarvas R (1952). On the flowering of birch and the quality of seed crop. Communicationes Instituti Forestalis Fenniae 40: 1-35.

Schirmer R (2006). Salix alba Linné. In: “Enzyklopädie der Laubbäume" [Encyclopedia of deciduous trees] (Schütt P, Weisberger H, Schuck HJ, Lang U, Stimm B eds). Nikol Verlagsgesellschaft mbH \& Co KG, Hamburg, Germany, pp. 535-550. [in German]

Schölch M (1998). Zur natürlichen Widerbewaldung ohne forstliche Steuerung [Natural reforestation without forestry interventions].
Schriftenreihe Freiburger Forstlicher Forschung 1, Forstliche Versuchs- und Forschungsanstalt Baden-Württemberg, Freiburg, Germany, pp. 245. [in German]

Seidl R, Schelhaas M-J, Rammer W, Verkerk PJ (2014). Increasing forest disturbances in Europe and their impact on carbon storage. Nature Climate Change 4: 806-810. - doi: 10.1038/nclim ate2318

Simpson RL, Leck MA, Parker VT (1989). Seed banks: general concepts and methodological issues. In: "Ecology of Soil Seed Banks" (Leck MA, Parker VT, Simpson RL eds). Academic Press Limited, London, UK, pp. 3-8.

Skoglund J, Verwijst T (1989). Age structure of woody species populations in relation to seed rain, germination and establishment along the river Dalälven, Sweden. Vegetation 82: 25-34. doi: $10.1007 / B F 00217979$

Sperens U (1997). Long-term variation in, and effects of fertiliser addition on, flower, fruit and seed production in the tree Sorbus aucuparia (Rosaceae). Ecography 20: 521-534. - doi: 10.1111/j.1600-0587.1997.tboo421.x

Spethmann W (2000). Generative Gehölzvermehrung [Generative propagation of woody plants]. In: “Krüssmanns Gehölzvermehrung” [Kruessmann's propagation of woody plants] (Mac Cárthaigh D, Spethmann W eds). Parey Verlag, Berlin, Germany, pp. 2-57. [in German] Staaf H, Jonsson M, Olsén L-G (1987). Buried germinative seeds in mature beech forests with different herbaceous vegetation and soil types. Holarctic Ecology 10: 268-277. - doi: 10.1111/j.160 0-0587.1987.tboo768.x

Sullivan KA, Ellison AM (2006). The seed bank of hemlock forests: implications for forest regeneration following hemlock decline. The Journal of the Torrey Botanical Society 133: 393-402. doi: 10.3159/1095-5674(2006)133[393:TSBOHF] 2.0.CO;2

Thompson K, Grime JP (1979). Seasonal variation in the seed banks of herbaceous species in ten contrasting habitats. Journal of Ecology 67: 893-921. - doi: 10.2307/2259220

Thompson K, Bakker J, Bekker R (1997). The soil seed banks of North West Europe: methodology, density and longevity. Cambridge University Press, Cambridge, UK, pp. 276. [online] URL: http://books.google.com/books?id=zGDcH 8f5n-wC

Thompson K, Bakker JP, Bekker RM, Hodgson JG (1998). Ecological correlates of seed persistence in soil in the north-west European flora. Journal of Ecology 86: 163-169. - doi: 10.1046/ j.1365-2745.1998.00240.x

Tiebel K, Karge A, Huth F, Wehnert A, Wagner S (2017). Strukturelemente fördern die Samenausbreitung durch Vögel [Structural elements promote seed dispersal by birds]. AFZ-Der Wald 20: 24-27. [in German]

Van Tooren BF (1988). The fate of seeds after dispersal in chalk grassland: the role of the bryophyte layer. Oikos 53: 41-48. - doi: 10.2307/ 3565661

Warr SJ, Kent M, Thompson K (1994). Seed bank composition and variability in five woodlands in south-west England. Journal of Biogeography 21: 151-168. - doi: 10.2307/2845469

Worrell R (1995). European aspen (Populus tremula L.): a review with particular reference to 
Scotland: I. Distribution, ecology and genetic variation. Forestry 68: 93-105. - doi: 10.1093/for estry/68.2.93

Young JA, Clements CD (2003). Seed germination of willow species from a desert riparian ecosystem. Journal of Range Management 56: 496-500. - doi: $10.2307 / 4003842$

Zerbe S (2001). On the ecology of Sorbus aucuparia (Rosaceae) with special regard to germination, establishment and growth. Polish Botanical Journal 46: 229-239.

Zerbe S (2009). Renaturierung von Waldökosystemen [Restoration of forest ecosystems]. In: "Renaturierung von Ökosystemen in Mitteleuropa" [Restoration of ecosystems in central
Europe] (Zerbe S, Wiegleb G eds). Spektrum Akademischer Verlag, Heidelberg, Germany, pp. 153-182. [in German]

Zobel M, Kalamees R, Püssa K, Roosaluste E, Moora M (2007). Soil seed bank and vegetation in mixed coniferous forest stands with different disturbance regimes. Forest Ecology and Management 250: 71-76. - doi: 10.1016/j.foreco. 2007.03.011

Zywiec M, Ledwon M (2008). Spatial and temporal patterns of rowan (Sorbus aucuparia L.) regeneration in West Carpathian subalpine spruce forest. Plant Ecology 194: 283-291. - doi: 10.1007/s11258-007-9291-z

Zywiec M, Holeksa J, Wesolowska M, Szewczyk
J, Zwijacz-Kozica T, Kapusta P (2013). Sorbus aucuparia regeneration in a coarse-grained spruce forest - a landscape scale. Journal of Vegetation Science 24: 735-743. - doi: 10.1111/j.16541103.2012.01493.x

\section{Supplementary Material}

Tab. S1 - Summary of the 33 seed bank studies in central and north-west European temperate forests selected.

Link:Tiebel_2400@supplo01.pdf 